\title{
In Vitro and Ex Vivo Evaluation of Cyclic Aminoalkyl Benzilates as Potential Emission Tomography Ligands for the Muscarinic Receptor
}

\author{
C. A. OTTO, ${ }^{1}$ G. K. MULHOLLAND, ${ }^{2}$ S. E. PERRY, ${ }^{1}$ R. COMBS, ${ }^{1}$ \\ P. S. SHERMAN ${ }^{2}$ and S. J. FISHER ${ }^{2}$ \\ 'Department of Natural Sciences, University of Michigan-Dearborn, Dearborn, MI 48128 and ${ }^{2}$ Division \\ of Nuclear Medicine, University of Michigan Medical Center, Ann Arbor, MI 48109, U.S.A.
}

(Received 20 April 1988)

\begin{abstract}
A series of muscarinic antagonists were screened as potential receptor imaging agents. $(+) 2 \alpha$-tropanyl benzilate (TRB), N-methyl-4-piperidyl benzilate (NMPB) and several analogs amenable to labeling with positron emitting isotopes were evaluated for muscarinic binding to mouse brain tissue in vitro and ex vivo using $\left[{ }^{3} \mathrm{H}\right]$ quinuclidinyl benzilate as the probe. The in vitro assay directly compared the innate binding affinities of the compounds. The rank order of binding $\left(\mathrm{IC}_{50}\right)$ was TRB $(0.7 \mathrm{~nm}), \mathrm{QNB}(0.8 \mathrm{~nm})$, scopolamine $(1.3 \mathrm{~nm})$ and NMPB $(1.6 \mathrm{~nm})$. The ex vivo assay was used to gain information regarding the pharmacokinetics and brain penetration of the compounds in live animals. Ex vivo results demonstrated that TRB was rapidly taken up into the brain and was equipotent with QNB in occupying muscarinic binding sites at early time points, but TRB binding decreased twice as fast over time as QNB binding. The results suggest TRB would be a good candidate for radiolabeling and further study.
\end{abstract}

\section{Introduction}

As part of an effort to develop new muscarinic receptor (mAChR) imaging agents for study of the central muscarinic cholinergic system using positron emission tomography (PET), we sought a method to allow screening of potential ligands in unlabeled form. It would be desirable if the screen yielded information about the penetration and retention of ligands in the brain in vivo as well as compare their in vitro binding affinities for the $\mathrm{mAChR}$. The screening procedure would be applied to a group of potent, centrally active muscarinic antagonists and analogs that could be labeled with high specific activity carbon-11 or fluorine-18 (Fig. 1). It was hoped that a combination of in vitro and ex vivo assays (Cho et al., 1986; Sethy et al., 1987) would provide answers to these questions and allow selection of promising candidates without resorting to expensive and time consuming radiosynthesis of each compound under initial consideration.

\section{Materials and Methods}

Drugs

Samples of $(+)-2 \alpha$-tropanol, nor- $(+)-2 \alpha$-tropanyl benzilate (nor-TRB) and nor- $(+)-2 \alpha$-tropanyl diphenylfluoroacetate (TRDFA) (Atkinson et al., 1983) were kindly provided by Dr Edward R. Atkinson. (+)-2 $\alpha$-Tropanyl benzilate (TRB) (Atkinson et al., 1977), 4-piperidyl benzilate (PB) (Biel et al., 1961), N-methyl-4-piperidyl benzilate (NMPB) (Biel et al., 1961) and ( \pm ) quinuclidinyl benzilate (QNB) (Meyerhoffer, 1972; Kadin and Cannon, 1962) were prepared by standard literature procedures involving base catalyzed transesterification of the respective aminoalcohols with methyl benzilate. Norscopolamine $\cdot \mathrm{HCl}$ was prepared from scopolamine (Schmidt et al., 1965). The following drugs were obtained commercially: $(-)$ atropine sulfate $\cdot \mathrm{H}_{2} \mathrm{O}$ (Aldrich), scopolamine $\cdot \mathrm{HBr} \cdot 2 \mathrm{H}_{2} \mathrm{O}$ (Sigma) and $\left[{ }^{3} \mathrm{H}\right] \mathrm{QNB}$ (specific activity $33 \mathrm{Ci} / \mathrm{mmol}$, DuPont NEN). N-(2-Fluoroethyl)-4-piperidyl benzilate (FEPB) and N-(2-fluoroethyl)nortropanyl benzilate (FENTRB) were prepared by reacting PB and nor-TRB respectively, with 2-fluoroethyl iodide and $\mathrm{K}_{2} \mathrm{CO}_{3}$ in refluxing acetonitrile, and purified by flash chromatography $\left(\mathrm{SiO}_{2}, 20: 1: 1\right.$ $\mathrm{CH}_{2} \mathrm{Cl}_{2}: \mathrm{MeOH}: \mathrm{Et}_{3} \mathrm{~N}$ ).

In vitro assay

Female CD mice (24-30 g, Charles River) were killed by decapitation under ether anesthesia. Brains were rapidly removed and the cerebellum discarded. 

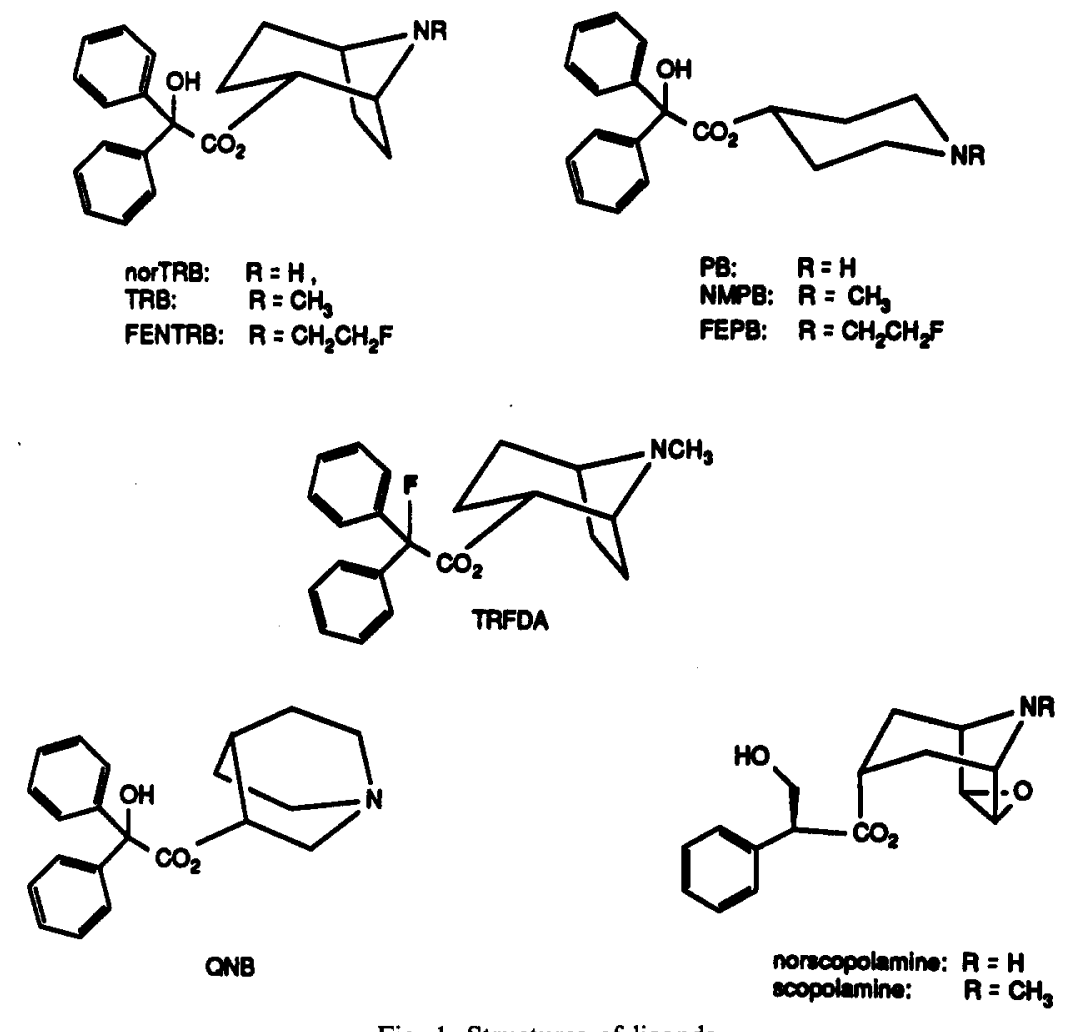

Fig. 1. Structures of ligands.

The remaining brain tissue was stored at $-80^{\circ} \mathrm{C}$ until used. For the assay, each brain was thawed and homogenized in $3 \mathrm{~mL}$ of ice-cold $50 \mathrm{mM}$ sodium-potassium $(\mathrm{Na}-\mathrm{K})$ phosphate buffer $(\mathrm{pH}$ 7.4) containing $10 \mathrm{mM}$ EDTA. The homogenate was kept on ice for $30 \mathrm{~min}$ and then centrifuged at $48,000 \mathrm{~g}$ for $10 \mathrm{~min}$. The pellet was resuspended in $5 \mathrm{~mL}$ of $\mathrm{Na}-\mathrm{K}$ phosphate buffer. Protein concentration was determined using the Bradford assay (standard: bovine serum albumin). Protein concentration of the homogenate was $6-7 \mu \mathrm{g} / \mu \mathrm{L}$. To assay the inhibition of $\left[{ }^{3} \mathrm{H}\right] \mathrm{QNB}$ binding to brain tissue, triplicate samples of $50 \mu \mathrm{L}$ of homogenate in $50 \mathrm{mM}$ $\mathrm{Na}-\mathrm{K}$ phosphate buffer containing $0.5 \mathrm{nM}\left[{ }^{3} \mathrm{H}\right] \mathrm{QNB}$ with and without varying concentrations of drugs were used. A minimum of ten different concentrations of each drug were used. Nonspecific binding was also determined in triplicate by including $1 \mu \mathrm{M}$ atropine in the assay. The entire assay was repeated at least twice with each drug. The assay was initiated by addition of homogenate to yield a final volume of $2.0 \mathrm{~mL}$ and incubated at room temperature for $60 \mathrm{~min}$. The assay was terminated by addition of $3.0 \mathrm{~mL}$ of ice-cold buffer followed by an immediate vacuum filtration using glass fibre filters (S\&S \# 32). Each filter was washed immediately and rapidly with $3 \times 3.0 \mathrm{~mL}$ of ice-cold buffer and transferred to a scintillation vial. After adding cocktail $(3.0 \mathrm{~mL})$ the vials were stored in the dark for $12 \mathrm{~h}$ and then counted ( $58 \%$ efficiency). The $\mathrm{IC}_{50}$ for each compound is the average of at least two separate studies conducted in triplicate. The $\mathrm{IC}_{50}$ values were determined from plots of ligand concentration vs percent inhibition of radiotracer binding and are tabulated in Table 1.

Ex vivo assay

Four mice were injected with drug dissolved in $0.1 \mathrm{~mL}$ of $10 \% \mathrm{EtOH} /$ saline vehicle. Control mice were injected with an equal volume of vehicle alone. Drug dosages ranged from $1 \times 10^{-7}$ to $1 \times 10^{-5} \mathrm{~mol} / \mathrm{kg}$. The dosages of $\pm \mathrm{QNB}$ were doubled to compensate for the presence of the inactive enantiomer. At designated times, the mice were killed as above, the brains were rapidly removed, and cerebellum discarded. Each brain was individually frozen at $-80^{\circ} \mathrm{C}$ until used. Assays were conducted

Table 1. $\mathrm{IC}_{50}$ values for various $\mathrm{mAChR}$ ligands obtained from competitive binding assays using $\left[{ }^{3} \mathrm{H}\right] \mathrm{QNB}$ in mouse brain

\begin{tabular}{lr}
\multicolumn{2}{c}{ homogenates } \\
\hline Drug & IC $_{50}(\mathrm{nM})$ \\
\hline QNB & $0.8 \pm 0.2$ \\
Scopolamine & $1.3 \pm 0.3$ \\
Nor-scopolamine & $6.9 \pm 0.9$ \\
PB & $17.3 \pm 2.7$ \\
NMPB & $1.8 \pm 0.1$ \\
FEPB & $6.4 \pm 0.4$ \\
TRB & $0.7 \pm 0.3$ \\
nor-TRB & $1.3 \pm 0.4$ \\
TRFDA & $8.5 \pm 1.0$ \\
FENTRB & $2.5 \pm 0.2$ \\
\hline
\end{tabular}


within 2 weeks of sacrifice. Immediately prior to assay, each brain was thawed and homogenized individually in $4 \mathrm{~mL}$ of $50 \mathrm{mM} \mathrm{Na}-\mathrm{K}$ phosphate buffer, $\mathrm{pH}$ 7.4. Homogenates were stored on ice ( $<10 \mathrm{~min}$ ) until added to the assay. Protein concentration was determined as above; concentrations ranged from $6-11 \mu \mathrm{g} / \mu \mathrm{L}$. The assay was conducted as above except that homogenate incubation was carried out at $37^{\circ} \mathrm{C}$ for $30 \mathrm{~min}$ and each brain was assayed in quadruplicate with and without $1 \mu \mathrm{M}$ atropine. The counts were corrected for background and normalized for protein concentration. Binding levels are expressed as $\mathrm{cpm} / \mu \mathrm{g}$ protein.

\section{Results and Discussion}

To the best of our knowledge, these in vitro and $e x$ vivo binding studies of TRB, NMPB and their analogs provide the first direct comparisons between these potent central muscarinic antagonists. No receptor binding studies have been reported for TRB or its analogs. Our attention was drawn to these compounds by live animal pharmacological studies which indicated very high potency (fourfold greater than QNB) and rapid onset of central effects for TRB and some of its analogs (Atkinson et al., 1977). The $\mathrm{N}$-fluoroethyl analogs FENTRB and FEPB have not been examined previously although a structurally similar quaternized N-fluoroethyl 3-tropanyl benzilate is reported to have potent peripheral anticholinergic actions (Bauer and Fugner, 1986). Extensive pharmacological data on NMPB have been collected (Kloog and Sokolovsky, 1977; Sokolovsky et al., 1980) and studies directly comparing in vitro binding of NMPB with QNB and scopolamine are available (Rehavi et al., 1978). The inclusion of these reference ligands in our test procedures helped to assess the validity of the results obtained.

In vitro assay: structure-binding relationships

$\mathrm{IC}_{50}$ values were determined for each ligand by means of traditional, competitive binding assays. Values for QNB and scopolamine were also obtained for comparison. The results are compiled in Table 1. The values for NMPB, TRB, scopolamine, FENTRB and nor-TRB were similar in magnitude to those of QNB.

Although TRB and NMPB had similar $\mathrm{IC}_{50}$ values ( 0.6 and $1.8 \mathrm{nM}$ respectively), the effects of demethylation were quite different. In the piperidyl series, demethylation decreased the binding affinity by an order of magnitude whereas in the tropanyl series, demethylation only reduced binding affinity by half. Replacement of $\mathrm{N}$-methyl by $\mathrm{N}$-fluoroethyl in TRB and NMPB reduced the binding by a factor of approximately 3 in each case. In other studies, the $\mathrm{N}$-propyl, N-cyclopropylmethyl and $\mathrm{N}$-allyl tropanyl derivatives showed peripheral effects comparable to TRB and nor-TRB (Atkinson et al., 1977). These

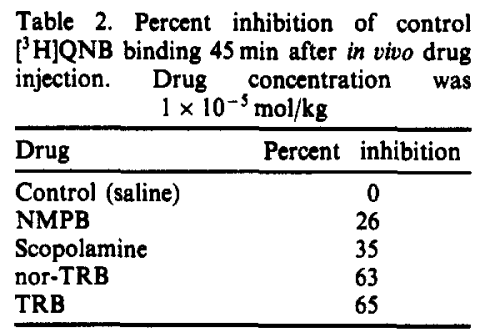

results suggest that there is some steric tolerance of the receptor binding site towards $\mathrm{N}$-substitution in the tropanyl series.

The fluoro analog TRFDA had an $\mathrm{IC}_{50}$ value of $8.5 \mathrm{~nm}$, however the position of fluorine attachment may be sensitive to hydrolysis to produce TRB. Further studies are necessary to establish whether the measured value represents the true binding affinity of TRFDA or is an overestimation caused by in situ formation of TRB from TRFDA.

\section{Ex vivo assay}

To assess brain penetration of the compunds, an ex vivo assay patterned on that used by Cho et al. (1986) and Sethy et al. (1987) was conducted. This ex vivo assay consisted of injection of unlabeled ligand into an animal followed by sacrifice and use of an in vitro binding assay to measure residual $\left[{ }^{3} \mathrm{H}\right] \mathrm{QNB}$ binding to brain homogenates. Several types of studies were performed: determination of effect of ligand and dose on receptor occupancy, and effect of time on receptor occupancy.

\section{Effect of ligand and dose on receptor occupancy}

Several ligands with low $\mathrm{IC}_{50}$ values were initially examined in the ex vivo assay at a dose of $1 \times 10^{-5} \mathrm{~mol} / \mathrm{kg}$, a pharmacologically active dose for NMPB (Sokolovsky et al., 1980). The percent inhibition of control $\left[{ }^{3} \mathrm{H}\right] \mathrm{QNB}$ binding at $45 \mathrm{~min}$ for TRB, nor-TRB, NMPB and scopolamine are summarized in Table 2. TRB occupied the most recep-

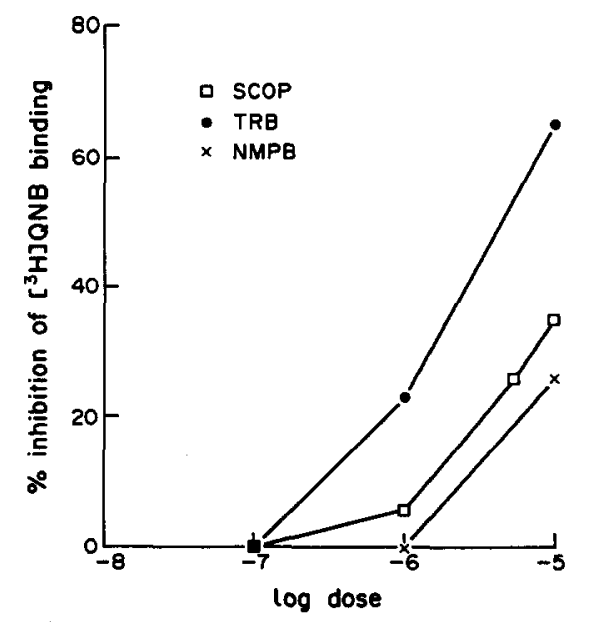

Fig. 2. The percent inhibition of control $\left[{ }^{3} \mathrm{H}\right] \mathrm{QNB}$ binding vs ligand identity and dose after i.v. administration of ligands to mice and sacrifice at $45 \mathrm{~min}$. 
tors, NMPB the least and scopolamine binding was intermediate. TRB and nor-TRB binding were nearly identical, suggesting similar brain penetration and retention for these two compounds. This further emphasizes the close biological resemblance between TRB and nor-TRB indicated in this work by the $\mathrm{IC}_{50}$ values and by the peripheral pharmacology data previously reported (Atkinson et al., 1977).

The range of doses tested in the ex vivo assay was extended from $1 \times 10^{-5} \mathrm{~mol} / \mathrm{kg}$ to $1 \times 10^{-7} \mathrm{~mol} / \mathrm{kg}$ for TRB, NMPB and scopolamine. The results are depicted in Fig. 2. TRB inhibited more $\left[{ }^{3} \mathrm{H}\right] \mathrm{QNB}$ binding than either NMPB or scopolamine at doses ranging from $1 \times 10^{-5}$ to $1 \times 10^{-6} \mathrm{~mol} / \mathrm{kg}$. The lowest detectable binding varied with ligand identity and apparently can be as low as $1 \times 10^{-7} \mathrm{~mol} / \mathrm{kg}$ as observed for TRB. As the assay was conducted at $37^{\circ} \mathrm{C}$ for $30 \mathrm{~min}$ it is probable that a portion of the ligand bound in vivo dissociated during the incubation; the measured value of $\left[{ }^{3} \mathrm{H}\right] \mathrm{QNB}$ binding inhibition is therefore a lower limit for ligand receptor occupancy at the time of sacrifice.

\section{Effect of time on receptor occupancy}

The effect of time on receptor availability was compared for QNB and TRB. The results, plotted as percent inhibition of control $\left[{ }^{3} \mathrm{H}\right] \mathrm{QNB}$ binding vs time are shown in Fig. 3. In this study, mice were injected either with QNB or TRB $\left(1 \times 10^{-5} \mathrm{~mol} / \mathrm{kg}\right)$ and sacrificed at designated times. The binding level for drug is expressed as a fraction of the binding level for controls. Both TRB and QNB demonstrated almost complete receptor occupancy at $2 \mathrm{~min}$ post injection. While the percentage of receptor vacancy increased with time for both compounds, the rate of increase was about twice as fast for TRB compared to QNB: $t_{1 / 2}=113 \mathrm{~min}$ for TRB and $234 \mathrm{~min}$ for QNB (correlation coefficients of $\ln C_{0} / C_{\mathrm{t}}$ vs time were

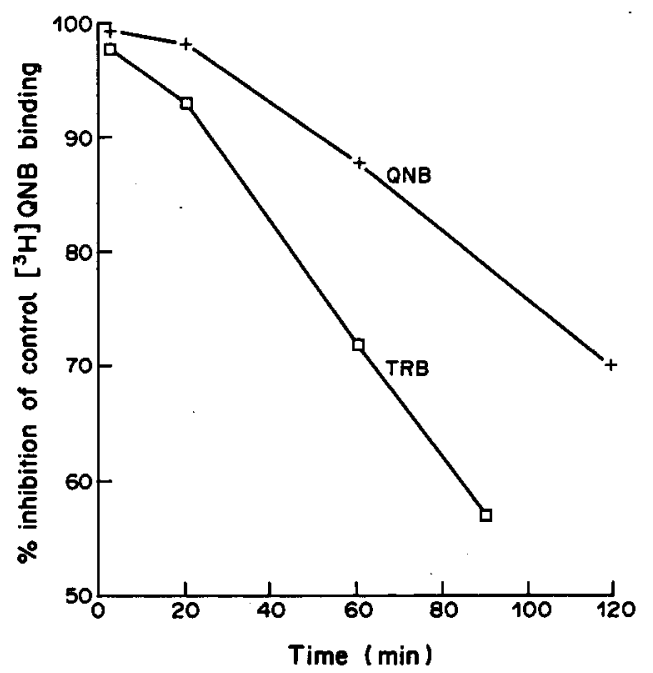

Fig. 3. Inhibition of $\left[{ }^{3} \mathrm{H}\right] \mathrm{QNB}$ binding at various time intervals after i.v. administration of $1 \times 10^{-5} \mathrm{~mol} / \mathrm{kg}$ doses of TRB or QNB to mice.
0.992 for TRB and 0.986 for QNB). It is noteworthy that these data are similar to the time course of anti-tremorine (central) effects of QNB and TRB previously reported (Atkinson et al., 1977).

Evaluation of receptor-based agents employing only in vitro studies suffers because normal physiological compartments and barriers are disrupted and tissue homogenization may expose more binding sites than are accessible in vivo. For example, striking differences between $\left[{ }^{3} \mathrm{H}\right]$ spiperone binding to in vitro homogenates, in vitro tissue slices and in vivo tissue samples have been described in normal and dopamine denervated rat striatal tissue (Bennett and Wooten, 1986). Although the ex vivo assay does not distinguish binding of parent drug from binding of active metabolites, it does provide a more realistic assessment of radiopharmaceutical potential than in vitro binding assays alone. The combination of in vitro competitive binding assays and estimation of in vivo receptor occupancy does not generate all the information needed to evaluate a potential receptor imaging agent, but it helps narrow the list of potential receptor-based agents without the need for prior radiosynthesis.

\section{Conclusion}

In vitro competitive binding assays have shown that several piperidyl and tropanyl benzilates have binding affinities for the mAChR comparable to QNB and scopolamine. Radiolabeled forms of QNB (Eckelman et al., 1984) and scopolamine (Frey et al., 1987; Mulholland et al., 1988) have been used to image the mAChR in human brain. These piperidyl and tropanyl benzilates may also serve as imaging agents. Ex vivo assay results indicate that TRB occupies more receptors than the other ligands examined and appears to be equipotent with QNB while possessing a faster rate of clearance from the brain. The accumulated evidence points to TRB as a likely candidate for radiolabeling and further evaluation as a PET agent for $\mathrm{mAChR}$ imaging.

Of considerable importance is that the ex vivo assay can be employed to (1) demonstrate CNS localization of a ligand or its active metabolites (2) rank ligands in terms of in vivo binding potency and (3) assess receptor clearance rates. Thus, the combination of both in vitro and ex vivo assays is beneficial in selection of potential imaging agents.

Acknowledgements-We are grateful to Dr Edward R. Atkinson for his ongoing interest and contributions to this project. The authors thank Ms Linder Markham for preparing the manuscript. Research was supported by Grant 2-P01-NS15655 from NINCDS and by Grants DE FG02 87ER60561 and DE FG02 87ER60528 from the Department of Energy.

\section{References}

Atkinson, E. R.; McRitchie, D. D.; Shoer, L. F.; Harris, L. S.; Archer, S.; Aceto, M. P.; Pearl, J.; Luduena, F. P. 
Parasympatholytic (anticholinergic) esters of the isomeric 2-tropanols. 1. Glycolates. J. Med. Chem. 20: 1612; 1977. Atkinson, E. R.; McRitchie-Ticknor, D. D.; Harris, L. S.; Archer, S.; Aceto, M. D.; Pearl, J.; Luduena, F. P. Parasympatholytic (anticholinergic) esters of the isomeric 2-tropanols. 2. Non-glycolates. J. Med. Chem. 26: 1772; 1983.

Bauer, R.; Fugner, A. Pharmacology of the anticholinergic bronchospasmolytic agent flutropium bromide. Arzneim Forsch./Drug Res. 36 (II): 1348; 1986.

Bennett, J. P. Jr.; Wooten, G. F. Dopamine denervation does not alter in vivo ${ }^{3} \mathrm{H}$-spiperone binding in rat striatum: implications for external imaging of dopamine receptors in Parkinson's disease. Ann. Neurol. 19: 378; 1986.

Biel, J. H.; Abood, L. G.; Hoya, W. K.; Leiser, H. A.; Nuhfer, P. A.; Kluchesk, E. F. Central Stimulants. II. Cholinergic blocking agents. J. Org. Chem. 26: 4096; 1961.

Cho, M. J.; Sethy, V. H.; Haynes, L. C. Sequentially labile water-soluble prodrugs of alprazolam. J. Med. Chem. 29: $1346 ; 1986$.

Eckelman, W. C.; Reba, R. C.; Rzeszotarski, W. J.; Gibson, R. E.; Hill, T.; Holman, B. L.; Budinger, T.; Conklin, J. J.; Eng, R.; Grissom, M. P. External imaging of cerebral muscarinic acetylcholine receptors. Science 223: $291 ; 1984$.

Frey, K. S.; Koeppe, R. A.; Jewett, D. M.; Mulholland, G. K.; Hichwa, R. D.; Kuhl, D. E.; Agranoff, B. W. (1987) The in vivo distribution of $\left[{ }^{11} \mathrm{C}\right]$ scopolamine in human brain determined by positron emission tomog- raphy. Society of Neuroscience 17th Annual Meeting, New Orleans, La, Nov. 16-21, p. 1658 (Abstract number 461.6).

Kadin, S. B.; Cannon, J. G. Esters of N-methy-3hydroxypiperidine having psychotomimetic activity II. J. Org. Chem. 27: 240; 1962.

Kloog, Y.; Sokolovsky, M. Muscarinic acetylcholine receptors interactions: competition binding studies with agonists and antagonists. Brain Res. 134: 167; 1977.

Meyerhoffer, A. Absolute configuration of 3-quinuclidinyl benzilate and the behavioral effect in the dog of optical isomers. J. Med. Chem. 15: 994; 1972.

Mulholland, G. K.; Jewett, D. M.; Toorongian, S. A. Routine synthesis of $\left[{ }^{11} \mathrm{C}-\mathrm{N}\right.$-methyl]-scopolamine by phosphite mediated methylation with $\left[{ }^{11} \mathrm{C}\right]$ formaldehyde. Appl. Radiat. Isot. 39: 373; 1988.

Rehavi, M.; Yaavetz, B.; Kloog, Y.; Maayani, S.; Sokolovsky, M. In vivo and in vitro studies on the antimuscarinic activities of some aminoesters of benzilic acid. Biochem. Pharm. 27: 1117; 1978.

Schmidt, H. L.; Werner, G.; Kumpe, G. Synthetischer einbau von ${ }^{14} \mathrm{C}$ in $(-)$ scopolamin, scopin und scopolin. Ann. Chem. 688: 228; 1965.

Sethy, V. H.; Francis, J. W.; Elfring, G. Onset and duration of action of benzodiazepines as determined by inhibition of $\left[{ }^{3} \mathrm{H}\right]$ flunitrazepam binding. Drug Dev. Res. 10: 117; 1987.

Sokolovsky, M.; Egozi, Y.; Koog, Y. Biochemical characterization of muscarinic receptors. Monogr. Neural Sci. 7 : $30 ; 1980$. 